\title{
From Low Jump to High Jump: Adventure Recreation and the Criminal Law in New Zealand
}

\author{
Pip Lynch, Lincoln University, New Zealand \\ and Paul Jonson, University of Technology, Sydney
}

Contacts:

Dr Pip Lynch, ESDD, PO Box 84, Lincoln University, Lincoln 7647, Canterbury, New Zealand.

Email: lynchp@lincoln.ac.nz

Dr Paul Jonson, School of Leisure, Sport and Tourism, University of Technology Sydney, PL Box 222, Lindfield 2070, Sydney, Australia.

Email: Paul.Jonson@uts.edu.au

\begin{abstract}
Until recently, New Zealand law set a very low threshold for culpability under criminal nuisance or criminal negligence and this threatened to impact negatively on the provision of adventure recreation. In 2004, a new interpretation of criminal nuisance was introduced and this, too, is potentially damaging for adventure recreation by raising the bar to criminal culpability too high. In this paper, we consider the implications of the law of criminal nuisance for New Zealand recreation in general, and we take risk recreations (also known as adventure recreations) as particular cases in which the threshold could have far-reaching detrimental consequences for recreation provision and participation. Comparison with interpretations of criminal negligence (and civil in Australia) in other common law jurisdictions and a review of the New Zealand adventure recreation culture shows that the swing from a low jump to a high jump for culpability is not in the best interests of recreation in New Zealand.
\end{abstract}

\section{$\underline{\text { Introduction }}$}

New Zealand has a tradition of, and now a world-wide reputation for, high levels of participation in physical recreation in general, and access to a wide variety of sporting opportunities and outdoor adventure recreational activities (Callander and Page, 2003). Mass participation in competitive sports and outdoor recreational events has recently emerged as an expression of this physical recreation culture. However, the recent cases of $\mathrm{R}$ $\mathrm{v}$ Andersen [2003, Unreported] and R v Andersen [2005] ${ }^{1}$ involving the organiser of a major sport and recreation event have highlighted the difficulties that exist for adventure event organisers, participants and the courts when this culture clashes with the criminal law.

\footnotetext{
${ }^{1}$ The Court of Appeal hearing was conducted in 2004 (hence reference to this date in the abstract and the conclusion of this paper) but not reported (published) until 2005.
} 
The Andersen cases arose from an accident that occurred during Le Race, 2001. Le Race is an annual (since 1999), 100km cycling event for recreational riders beginning in the city of Christchurch, New Zealand and finishing in the harbour town and one-time French settlement, Akaroa. The event is organised commercially by a private professional (Astrid Andersen) and in 2001 it attracted approximately 1,000 participants. The event organiser set out event rules and conditions which included staying on the left hand side of the road (correct in New Zealand) at all times. This rule was repeated several times in instructions given to participants. It was also stated in the pre-race literature and immediately prior to the commencement of the race by Andersen, that there was 'an official road closure on the Summit Road' (Le Race Starter Pack information sheet, 2001; emphasis added). There are two roads on the Le Race course that carry the name 'Summit Road', although it is not clear that participants (including the deceased) were aware of this at the time. These two roads are some 40km apart. The 'official road closure' was on the first (commonly recognised) Summit Road, near Christchurch and the accident occurred on the second Summit Road, near Akaroa. 'Road closure', as became clear in the trial (R v Andersen, [2003, Unreported]), was intended to mean a 200metre area at the top of the first Summit Road where cyclists would be checked as to being officially entered and then allowed to proceed. However some witnesses gave evidence in the trial that they (variously) understood the phrase to mean the that whole of the first Summit Road, or the whole of both roads bearing that name, was closed.

Participants could ride the entire distance or compete in two-person or four-person teams. One cyclist (the final member of a four-person team) commenced her ride along the second Summit Road and had a winding hilltop road to peddle before a steep descent to the finish. The first straight section of road in her leg of the event was approximately $100 \mathrm{~m}$ long and just before the end of this straight she collided with a car that had come around a blind, right hand bend. The cyclist was travelling on the wrong side of the road at the time of impact and died as a result of the collision.

The event organiser, Andersen, was charged and convicted of criminal nuisance under ss 145 and 156 of the New Zealand Crimes Act 1961 for giving what was found to be a misleading and therefore negligent instruction regarding the road closure ( $\mathrm{R} v$ Andersen, [2003 Unreported]). The decision however was reversed on appeal ( $\mathrm{R} v$ Andersen [2005]).

This paper will consider the law of criminal nuisance and criminal negligence in New Zealand and its implications for recreation provision. At issue are the distinctions drawn between criminal nuisance (or ordinary negligence), which is defined as carelessness; gross negligence, which is defined as a serious or major departure from accepted standards of care; and recklessness which is defined as a wanton disregard for the safety of others (McMullin, 1995). We will argue that the interpretation of the law of criminal nuisance (ordinary negligence, or carelessness) made by the Andersen conviction, as it pertains to the organisation and provision of adventure recreational events, was not only out-of-step with other common law jurisdictions, but more importantly, it was out of step with New Zealand society and New Zealanders' values in relation to leisure because it created too low a bar for criminality. Empirical evidence from an informal survey indicates that it created a situation whereby persons who provided facilities and opportunities for physical recreation, including risk (or adventure activities), had reason to fear that they could be found guilty of a criminal offence for an inadvertent error of judgement in contexts in which risk is sought and encouraged. We further argue that the Andersen appeal decision, in which the conviction 
was overturned, is also problematic because it raises the bar to criminality too high (beyond gross negligence to recklessness). In our view, as a result of the Andersen cases, the law in New Zealand has swung from creating too low a jump to too high a jump for criminal negligence and that further change is needed - a shift to the midpoint of gross negligence. We first discuss adventure recreation in the New Zealand context then reflect on the leisure, and accident, theories that inform our critique of the Andersen cases and their effects or potential effects on New Zealand adventure recreation.

\section{New Zealand Sport and Recreation Culture}

New Zealanders are among the most physically active nations in the Western world. This fact is illustrated in Table 1 below, which compares the best available data on overall physical activity rates in the four common law countries relevant to our analysis of criminal nuisance and negligence in law. The table shows reported participation in physical leisure activities for adults in each country. Method-related and statistical limitations may account for some of the differences between nations, but are unlikely to alter the result markedly: New Zealanders are significantly more physically active than are Australians, Canadians and the English.

\section{Table 1 here.}

It is worth noting in a little detail two of the method-related issues embedded in the participation data, for they further illustrate the main point. First, definitions of 'physically active' differ between countries. In the New Zealand and English surveys, respondents were considered to be physically active or moderately active if they had taken part in at least 2.5 hours of physical activity in the 7 days prior to interview. The Canadian definition was also based on 30 minutes of exercise per day but it is not clear if this was taken over a one-week period or longer. Australian adults were categorised in three levels of physical activity based on the number of times they participated in physical leisure each week. The minimum level of activity for inclusion in the 'active' categories was one activity session per week, of any duration. This leaves open the possibility that the level of physical activity among Australians would decline if the New Zealand or English categorisation were applied. Importantly, the New Zealand definition is at least as demanding as those of other nations, thus underscoring the primary observation.

Second, there are differences between the surveys with regard to age of respondents and this has an impact on comparability of the survey results. For example, in the Canadian statistics, adults are defined as being 20 years of age or older, compared to 15, 16 and 18 in the Australian, English and New Zealand statistics, respectively. As a general rule, younger people are more active than older people, in part due to the effect of compulsory physical education and, in some cases, compulsory sport in school. Given this, it is reasonable to expect higher overall participation in physical activity in countries where surveys included younger respondents. The Australian and English figures are all the more remarkable, then, especially when compared to those for New Zealand. Even with the younger age groups included, participation does not match that of New Zealanders. On the other hand, the Canadian picture may be somewhat bleaker than is really the case but it is unlikely that the difference is of a magnitude to disrupt the main point being made here - that New Zealanders are, in general, relatively highly physically active. It is this level of activity that the New 
Zealand Ministry of Health and Sport and Recreation New Zealand want to maintain and increase, for physical welfare reasons.

Our argument regarding the recreational culture in New Zealand goes beyond participation by putting the case that New Zealanders have a high participation rate in a particular type of recreation - that is, risk, or adventure, recreation. The terms 'risk recreation' and 'adventure recreation' are used interchangeably in this paper because adventure, in any sense of the word, involves risk. Internationally comparative data is not available for a wide range of risk recreation activities, but some comparisons with Australia, and to a limited extent with England, are possible. Table 2 lists a selection of physical recreations, some of which are general (aerobics/fitness, golf, netball, soccer, swimming, walking) and some of which are risk-related (cycling, fishing, equestrian/horse riding, ice-snow sports, motor sports, running, sailing, surf sports, triathlon, bush-walking/tramping). The general recreations serve as 'indicator' recreations to further illustrate the relative participation rates between countries. The risk-related recreations are indicators of the extent to which New Zealanders have access to, and willingly engage in, activities in which injury is an obvious and potential outcome and inherent risk.

The participation rates shown in Table 2 are by proportion of the physically active adult population. Cycling, running and motor sports involve proximity to motor vehicles, with potential for collision with those vehicles. Cyclists and runners often use roads for training and/or competitions and are therefore at risk of being hit by moving vehicles, even when participating in organised events (as was the situation in R v Andersen [2003, Unreported]. Triathletes are similarly exposed to road-related risks. Fishing, sailing and surfing inevitably involve the risk of drowning. Horse riding of any sort exposes participants to injury from falls and from the animals themselves. Falling is a common risk in snow and ice recreations, too, and in snow there are added potential hazards in the stability of the snow pack and in weather conditions. Inherent risks involved in bush walking in Australia include snake or insect bite, lightning strike, bush fires, dehydration and hyper/hypothermia. In New Zealand, trampers have to weigh up risks in river crossings, falls, and hypothermia.

Table 2 here.

As Table 2 shows, a greater proportion of physically active New Zealanders than physically active Australians participate in selected risk recreations. The reasons for this are not obvious but may include access to venues for those recreations, and a culture of risk-taking which, if not actually encouraged, is at least not discouraged by the legal environment itself through the accident compensation legislation. One of the positive consequences of this state of affairs appears to be a high level of physical activity participation, including participation in adventure activities.

Our argument is that risk recreations should be viewed contextually in the law. This view is informed by the leisure theory and by understanding the nature of recreation and the purpose of risk in recreation.

Leisure Theory, Recreation and Risk in New Zealand. 
Recreation is understood as a state of mind, central to which are perceived freedom and intrinsic motivation (Neulinger, 1981). Values associated with physical recreation and sport participation include physical health and fitness, skill mastery and excitement (Kelly, 1990). Additional to these are values associated with outdoor recreation pursuits that include locus of control, sensation-seeking, challenge and risk (Ewert, 1989). Arguably, New Zealanders have embraced a culture of recreational adventure whereby active risk-seeking is normalised at the level of culture and, for some, at the level of the individual. Recreational events involving physical challenges, we suggest, have become like outdoor recreation in terms of the values (motivations) associated with them. Le Race, for example, is a challenging cycling event through which participants may seek physical fitness, skill mastery, excitement, risk taking/controlling, and sensation-seeking outcomes.

Recreation has become a taken-for-granted aspect of life for most Western peoples. According to developmental, social identity, and humanist theorists of leisure, some people want or need something more than re-creation or rejuvenation; they strive to create a particular persona (Kelly, 1990). For some people, this socio-psychological development occurs through deliberate engagement with risk. Sensation-seeking (Zuckerman, 1990) drives risk-taking, at least initially. Experienced participants may return to the same risk activities for the ancillary benefits they accrue, such as social interaction, pleasure from physical exertion, proximity to nature and 'high-risk identity' (Creyer, Ross and Evers, 2003:242; and see Fluker and Turner, 2000:385; Eiser, 1994; Eiser, Cleisson and Loose, 1998; and Pidgeon, Kasperson and Slovic, 2003), while for beginners and veterans alike, adventure outcomes result from matching risk with competence (Mortlock, 1987; Ewert, 1989; Ewert and Hollenhorst, 1989; Csikszentmihalyi and Csikszentmihalyi, 1999; Priest, 1999). Ewert (1989) succinctly sums up this argument: Risk emerges when there is a loss of control or predictability. Control becomes an important fact in distinguishing between something that is difficult and something that is foolhardy (p3). Risk or adventurous recreationists, then, seek situations in which to test their ability to control the outcomes of participation, and New Zealand has become a haven for adventure recreation.

Recreational activities in backcountry areas have been a feature New Zealand's history and economy since colonisation in the nineteenth century (Devlin and Booth, 1998), and both outdoor/backcountry recreation and adventure tourism have grown rapidly since the 1970s. Cloke and Perkins (1998) give as an example of this growth, the fact that 'before 1976 there were fewer than 10 professional rafters operating on New Zealand rivers but this had increased to 50 by 1986' (p274). Further, the available data on adventure activities suggests that participation by international visitors to New Zealand in these activities has increased over $600 \%$ since the early 1990 s (see Table 3 ).

Table 3 here.

During the past 20 years, branding of New Zealand as a young, fresh, unspoilt and innovative tourist destination has provided strong cultural as well as economic elements in the growth of adventure tourism (Cloke and Perkins, 1998; Callander and Page, 2003). This strategy has promoted a view of New Zealanders as risk-takers and innovators within and beyond the realm of recreation and has driven continual experimentation with bigger, better and more exciting thrills in the outdoors environment (Cloke and Perkins, 1998: 282). The adventure imperative has also influenced sport and more traditional recreations. The growth of freedom recreations such as snowboarding, mountain biking and skateboarding, the rise of commercial 
and professional sports, and the advent of events in both the recreation and tourism domains have given rise to an adventure recreation event sector in New Zealand. Adventure recreation events typically comprise strenuous physical activity, usually involving considerable endurance and various levels of risk, in outdoor settings. They include ultralong distance running and cycling, multi-sport and extreme triathlons such as Ironman competitions, endurance orienteering (rogaining), extreme skiing and snowboarding, bungee jumping, base jumping, white-water rafting, and high-altitude mountaineering.

Strenuous endurance events have arisen as the recreation fashion of the 1990s and early twenty-first century (Creyer et al, 2003). Comprehensive listings of events in any one country are hard to find, as many events are run by small, local clubs on a not-for-profit basis. A web search ${ }^{1}$ using keywords 'multi + sport + Zealand' provided evidence of the popularity of competitive physical endurance events in New Zealand. 'Runnersweb' listed over 130 links to multisport events, tours, directories, equipment suppliers, advisers and the like in the Americas, Europe, Britain, Australasia and Asia. The Multisport Calendar for the South Island of New Zealand included 22 multisport events, 34 triathlons and duathlons, 15 kayaking races, 1 sea kayaking event, 23 road or mountain run/walk events, 8 rogaining events, and 38 mountain bike or cycling events scheduled for the period September 2003 to May 2004. One of the cycle events listed was Le Race. Many events provide for relay teams as well as individual competitors. Typically, these events attract both novice and experienced athletes, although those involving kayaking (such as the Coast to Coast) and/or remote backcountry travel (as in the Southern Traverse) usually require evidence of proficiency before entry is confirmed (see websites, Coast to Coast and Southern Traverse). Mass participation is a characteristic of these events in New Zealand; this feature makes events financially viable and provides commercial opportunities for entrepreneurial event organisers.

Endurance eventing in New Zealand draws on popular national (pakeha) myths of pioneering spirit, outdoor living, toughness, independence and valorisation of wilderness. The annual Coast to Coast multisport event involving over 200 kilometres of cycling, running and kayaking from one side of the South Island to the other, for example, began when outdoorsmen Robin Judkins and Peter Tocker conceived of a summer (February) race through terrain and landscapes they had learned to love both for the physical challenge of the travel and for natural beauty (McKerrow and Woods, 1994). McKerrow and Woods (1994) encapsulate the spirit of multisport eventing in New Zealand with this reflection from the 10year anniversary of the inception of the Coast to Coast:

...there is no denying the event has become incredibly popular because it fits the shape and character of the New Zealand psyche. It's a rugged, physical, successful thing to do. It's New Zealand's own, crossing from one side of our small but beautiful country to the other (p9).

The physical challenge and the unpredictability of the natural environment are intrinsic to the endurance racing ethos.

\section{Adventure and Accountability for Accidental Injury}

The risks involved in adventure recreations include physical injury and fatalities. According to Cloke and Perkins (1998), New Zealanders have learned to accept that death or injury is 
part of outdoor life but recent applications of criminal law suggest that that acceptance may have begun to weaken as contemporary public attitudes towards accidents and accountability change.

As numbers of participants in adventure recreation events has grown, so too has the simple numerical risk of serious injury or fatality (Creyer et al, 2003). However, this alone does not fully explain the recent emergence of criminal prosecutions for negligence under (criminal) nuisance. The way in which accidents are conceptualised has also had an effect. Until recent decades, according to Christoffel and Teret (1993), accidental personal injuries were viewed as 'random, uncontrollable' (p3), 'unpredictable, unavoidable' (p6) occurrences resulting from carelessness between individuals. It is only since the 1960s that a socially oriented view of accidents has emerged (in the USA and, arguably in NZ) and this view seeks to understand injury events more holistically. (The 1960s also spawned victimhood, according to Furedi (1997). He claims that it has now come to 'acquire the character of a permanent identity' (p98)). 'Multiple-causation' (Christoffel and Teret, 1993:7) models of injury direct attention towards prevention and stimulated development of scientific approaches to predict and control accidents and to manage the risks of accidental injury.

Two further catalysts of the social policy view of personal injury are public expectations of health, and public concern for accountability. Twentieth century improvements in general health care, sanitation and medical technologies have given most Westerners not only longer life expectancies but expectations of uncompromised, sustainable, physical well-being (Jones and Hood, 1996). One consequence of this appears to be that people are more willing to seek legal redress for personal injuries than they used to be (see Campos (1998) for an American view on this), and they may have greater expectations that the authorities will punish those whose actions or inactions result in physical harm to, and therefore diminished well-being of, others.

New Zealanders' concern for accountability appears to have increased markedly since the 1970s. Learned explanations for this apparent shift are elusive but some distinct possibilities can be identified. First, the economic difficulties of the decades since the 1970s in New Zealand (Hawke, 1992) have fostered general concern about costs of public services, including health care (Rice, 1992). This has led to close scrutiny of avoidable costs, such as accidental injury related costs (Campbell, 1996; Duncan, 2002; Rennie, 1995). Additional demands for accountability for the consequences of accidents have erupted in the wake of two mass tragedies - the Erebus disaster of 28 November 1979 (Mahon Report) and the Cave Creek tragedy of 28 April 1995 (Noble Report, 1995). The latter, in particular, stimulated closer scrutiny of risk management procedures in the government sector (see, for example Department of Conservation, 1995; Isaac, 1997; State Services Commission, 1998; Hunt, 2005) but both contributed to a general distrust of corporate risk management by the NZ public. This is consistent with trends elsewhere, as noted by Wells (1995:178): 'An increased tendency toward greater legislation has accompanied a decline in confidence in major institutions, business and government'.

All of these factors have combined to produce in New Zealand a paradoxical situation in which accidental injury is arguably less well tolerated than in the past despite the rise of a risk recreation culture. During the 1990s and since the turn of the millennium, this reduced tolerance for injury began to extend into the recreational arena and since New Zealand's accident compensation scheme bars tort remedies for personal injury, and the country's 
health and safety legislation often does not cover all recreational situations (ie. it deals with workplaces), criminal prosecution has become an obvious mechanism for public admonition of those found to be responsible for accidents. The nature of recreation provision and management in New Zealand, though, is such that criminal proceedings have caused substantial alarm and, as we will show below, there has been concern about long-term repercussions for the recreational culture of the nation.

\section{Criminal nuisance and criminal negligence.}

In R v Andersen [2003, Unreported], the defendant was accused under s156 of the New Zealand Crimes Act, 1961, of being in charge of a dangerous thing - the cycling event - and therefore having a legal duty to take reasonable precautions to avoid danger and under s 145 she was accused of having omitted to fulfil that duty.

Section 156 of the Act sets out the 'Duty of persons in charge of dangerous things' and states:

Every one who has in his charge or under his control anything whatsoever, whether animate or inanimate, or who erects, makes, operates, or maintains anything whatever, which, in the absence of precaution or care, may endanger human life is under a legal duty to take reasonable precautions against and to use reasonable care to avoid such danger, and is criminally responsible for the consequences of omitting without lawful excuse to discharge that duty.

Section 145 of the New Zealand Crimes Act 1961 states, under the heading 'Criminal Nuisance':

Every one commits criminal nuisance who does any unlawful act or omits to discharge any legal duty, such act or omission being one which he knew would endanger the lives, safety, or health of the public, or the life, safety, or health of any individual.

According to Simester and Brookbanks (2002), 'dangerous thing' can be interpreted widely, but at the time of the trial this had only been applied to tangible entities including motor vehicles, motor boats, firearms, explosives, toxic substances, a can of petrol, an unclean (human) food factory, bodily fluid containing HIV (but, interestingly, not a human person) (pp555-557) and jet-skis (The Queen v Tomasi [1998], The Queen v Hare [1999]). In R v Andersen ([2003] DCR 506) the interpretation of 'dangerous thing' was broadened to include intangible things - namely, recreational events. This application of the criminal law to the sport and recreation domain caused significant consternation amongst organisers and leaders of sport and recreation events and activities (as we later discuss).

However, as indicated, what is more worrying for sports and recreation leaders in New Zealand is the standard of care which a sport and recreation organiser is required to maintain to avoid a criminal conviction. Both the standard required at the time of the Andersen trial and the change to that standard brought about by the subsequent Appeal are the focus of this paper. In 2003, based on the trial court decision in R v Andersen (R v Andersen, [2003, Unreported]), for offences under s145 in connection with s156 (and s155) (NZ Crimes Act, 1961) the law only required mere carelessness or inadvertence to establish a guilty finding. 
In his comments on sentencing Andersen ( $\mathrm{R} v$ Andersen, [2003, Unreported]), the judge acknowledged that the degree of negligence found in the accused 'was neither reckless nor intentional but was merely careless' and that, overall, Andersen had been 'very concerned about the safety issues relating to Le Race 2001' ( at para 72). It is worth restating here that there is a distinction to be drawn between: 'mere or ordinary' negligence - carelessness; 'gross' negligence - a really serious or substantial departure from accepted standards; and 'recklessness' - a wanton or reckless disregard for the lives or safety of other persons (McMullin, 1995:21-3). After the trial, then, a mere mistake made without any intention to cause harm and which could be a minor departure from recognised best practice could result in a prison term. In our view, this was too low a bar for criminal liability, especially in the context of adventure recreation events. The trial judge in the Andersen case acknowledged the difficulty raised by the conviction and noted ( $\mathrm{R}$ v Andersen, [2003, Unreported], at paras 63-65) that the 'outcome of this case could responsibly result in further debate' about Sir Duncan McMullin's (McMullin, 1995) recommendation to extend the definition of negligence to gross negligence under criminal nuisance.

McMullin, a retired Appeal Court judge, compared New Zealand law with regard to manslaughter to relevant law in other jurisdictions and his findings usefully inform our discussion regarding recreation. Sir Duncan noted the divergence of New Zealand law from the law in England, Australia and Canada. Significantly, he noted (1995:19) the comments of the English Law Commission (made in its Consultation Paper on Involuntary Manslaughter, No. 135, 1994):

It described the New Zealand law as a "very severe law", couched in terms of mere civil negligence, the effect of which was sought to be mitigated by the hope that juries would not often convict and, if they did, a purely minimal penalty could be imposed. It said, "We cannot accept that this degree of uncertainty, and hazard for defendants, is a proper way of formulating offence of homicide". Most other jurisdictions have equally found such a rule unsatisfactory.

The position for 'involuntary manslaughter' in England was then (and still is) 'that there can be no conviction unless gross negligence is proved. In practice, this will mean a really serious or substantial departure from accepted standards' (McMullin 1995:21, emphasis added).

Sir Duncan (McMullin 1995) further noted that the 'Common Law in Australia is that carelessness or simple negligence is insufficient to warrant a conviction of manslaughter.... [there is a] requirement of gross negligence' (p. 22) and in Canada 'Everyone is criminally negligent who (a) in doing anything or, (b) in omitting to do anything that it is his duty to do, shows wanton or reckless disregard for the lives or safety of other persons' (p.23, emphasis in the original) and concluded 'a person may be convicted in New Zealand of manslaughter by negligence for being 'not very' careless. Other jurisdictions require much more' (p.24). We argue, as did Sir Duncan (see below), that the issue in relation to criminal nuisance was the very same as that for manslaughter in New Zealand.

In Australia, recent legislation (for example the Civil Liability Act, NSW 2002) has made it harder for sport and recreation event organisers to be sued for civil negligence such that those persons will not be liable for any harms arising from inherent or obvious risks or for dangerous risks of which they have given notification. This raises the possibility that a person 
in New Zealand could be found guilty of a criminal offence for behaviour, which under Australian law, they would not even be found civilly liable. For example if a rugby referee allowed scrums to continue to collapse and after one scrum collapsed late in the game a person in the scrum died as a result of an injury sustained due to that collapsed scrum, it is probable that in Australia the deceased party's estate would have no claim for compensation under the civil law of negligence, yet in New Zealand the referee could end-up in prison!

Sir Duncan accepted that 'the need for accountability is important (and) the public have the right to expect that people who take on responsibilities... are accountable if death or injury result from their negligent acts or omissions' (1995:39). But he nonetheless felt that there was need for changes to the law and that for negligence to be established in a criminal context there should be 'a "major departure" from the standard of care expected of a reasonable person in all the circumstances' (1995:45, emphasis added).

McMullin's recommendations went beyond just those sections of the Act that he was asked to consider. He recommended 'that the 'major departure' formula should be adopted for all crimes in which negligence is an element', including ss.145 and 156 (McMullin, 1995:50). One of his reasons for this recommendation was that it would foster 'the maintenance of good health' (McMullin, 1995:48). Although he was referring to the community health consequences of New Zealand's 'harsh law', stifling medical misadventure disclosures and therefore investigations, the point also applies to the sport and recreation management profession. To paraphrase Sir Duncan into the context of sport and recreation management, his suggested amendment would lead to the maintenance of an appropriate risk environment, and avoid the trend for less risky and indeed fewer recreational opportunities, the latter potentially diminishing the maintenance of physical health. Because the fear of prosecution would be reduced, improved accident reporting was likely to occur leading to greater accountability and an improvement in services. (On the latter issue, regarding blame, see Horlick-Jones (1996) and Johnston (1996)). As Sir Duncan went on to say '[r]isk must be balanced against the gains which far outweigh them' and he quoted the venerable Lord Denning (Roe v Ministry of Health; Woolley v Same [1954] 2 All ER 131):

But we should be doing a disservice to the community at large if we were to impose liability ...for everything that happens to go wrong.... Initiative would be stifled and confidence shaken...We must insist on due care...but we must not condemn as negligence that which is only misadventure.

As Sir Duncan notes, while Lord Denning was referring to 'a fear of liability in civil cases (it) is of even more importance when considering liability to criminal prosecution' $(1995 ; 48)$.

In the outcome, McMullin's recommendation in respect of s145 was not accepted (Simester and Brookbanks, 2002). Sport and recreation organisers, then, were still vulnerable to prosecutions for ordinary negligence. With regard to the sporting and recreational culture in New Zealand, this seemed curious. As noted above, risk and adventure were openly encouraged in New Zealand, in recreation and other spheres. What the law appeared to ignore was that risk, by definition, gives rise to loss. We are not arguing that recreation event organisers should not take care to prevent loss, rather that in activities in which risk is positively sought, the degree of negligence that should be required for a criminal conviction should be gross negligence. That is, criminal liability should reflect the nature of the society and the culture of recreation. 


\section{Impacts on Recreation}

Criminal law is a means by which the State protects the fundamental rights of its citizens: 'Criminal laws are deployed to control behaviours and events because there is a public and political interest in doing so' (Simester and Brookbanks, 2002:3). The Andersen prosecution, and before it, a motorsport prosecution, illustrate that in New Zealand, the law is being applied in novel contexts as recreation participation patterns, recreation management practices and societal attitudes to risk, change. The response of the District Court ( $\mathrm{R} \mathrm{v}$ Andersen, [2003, Unreported]) in the Le Race case was to signal that adventure recreation events come within the ambit of the criminal law and that event organisers found to have behaved negligently will be punished. The prosecution and conviction had the effect of enhancing the awareness of an already nervous recreation and sport community in New Zealand to its liabilities under criminal law, with both positive and negative impacts on recreation provision.

An informal survey of event organisers and participants in the wake of the Andersen prosecution and conviction illustrated that many event organisers were reconsidering staging their events. The survey was undertaken by one of the authors after receiving several unsolicited comments from event organisers and participants. It was intended to elicit information on the range of effects of the Andersen conviction for the purpose of informing future potential formal empirical investigation. The potential for the information gathered to be used in future investigations of law reform was also signalled in the email message sent out. For the purposes of this paper, the survey results merely illustrate the point that concern about the effects of the conviction was expressed by event organiser, leaders and participatnts. No greater claim that this is made. The survey involved a search for relevant New Zealand newspaper articles for the period March 2001 - June 2004 and a 'snowball' email questionnaire in June 2004 to known event participants, organisers and their contacts. This method was required because there was no comprehensive database of commercial and non-commercial event organisers in NZ and because the best way to contact event participants was via event organisers. A drawback of the method is that it may have elicited more responses from those who considered the law too strict than from those who considered the law appropriate, but this limitation does not diminish the validity of the information gained on events affected. The questionnaire requested three pieces of information: first, the name or type of event; second, the contact details for the event organiser; third, how the event had been effected by the Andersen conviction. Positive and negative effects were sought. The email 'snowball' elicited 55 responses. Forty-seven newspaper articles were found and an additional two articles were received from respondents, one from a national events newsletter and the other from the national weekly education gazette. The articles and emails were filtered for factual information about effects on events. Substantiation between published and unpublished sources was sought; where discrepancies occurred none of the information relating to the event was included in the final list of effects.

Effects on sport and recreation events were not created only by the Andersen case. Costs of compliance with increasingly rigorous traffic management regulations, and changes to the Health and Safety in Employment legislation were also factors, but in each case the Le Race accident and its repercussions were cited as features of the context within which event management decisions to cancel were made. 
Not all the effects reported were entirely negative. Many respondents referred in general terms to increased attention being given to risk management planning and procedures and this may have accident prevention outcomes. The social utility of the majority of effects reported, though, is less obvious.

Among the specific effects was cancellation of 39 events, including a cycle race that had, until 2003, run for 106 years. Events cancelled were predominantly cycling, running, multisport and triathlon events, while kayaking, rafting, horse racing, snowboarding/surfing, boxing events, a Christmas parade, a vintage car parade and Masters ocean swims were also cancelled. Among these cancellations were fundraising events to assist community and school projects. It is not clear that all these events were cancelled permanently but anecdotal evidence is that some were not run again. At least four events or projects were postponed in the wake of the Andersen decision ( $\mathrm{v}$ Andersen, [2003, Unreported]) and these included a marathon event, a cycling event, a 'duckboat derby', and the provision of a place for 'boy racers' ${ }^{2}$ to congregate.

Some events were modified to either reduce organisers' liability or comply with local authority traffic management requirements. Modifications included changing running and cycling routes, cancelling the kayak leg in a multisport event, turning a Christmas parade into a non-vehicular street festival (in one case) or a walk (in another), handing out sweets in a basket rather than by the traditional method of a lolly scramble, and having children sit on a chair rather than on Santa's knee. It was not only event organisers (volunteer and professional) who reacted to the new awareness of liability in sport and recreation events. Several volunteer kayak club instructors withdrew their services and leaders of tramping and mountaineering club trips expressed concern about their vulnerability to criminal prosecution. From the participants' point of view, physical recreation opportunities, especially those available via adventure recreation events, were at stake.

Among the more general effects expressed by respondents to the survey were increases in compliance costs for road-using events, increases in insurance costs, difficulties in finding volunteers to organise and assist with events, difficulties in gaining access to land (e.g for mountain biking and paragliding), and increases in entry fees. For two cycling enthusiasts, the latter effect barred them from participating in one event.

The survey results conflicted markedly with the trial judge's comments on the effect of the Andersen conviction:

... since the verdict there have been a number of wild pronouncements in the media and by sporting organisations and event organisers that the verdict on the criminal nuisance charge ... is the death knell to the sporting culture of this country as we know it. This is utter nonsense. Nothing could be further from the truth ... there is no reason whatever to suggest that people who are involved in organising sporting or other events have any justified cause for alarm as a result of the verdict in this case. (R v Andersen, [2003, Unreported], paras 39-40).

The evidence of cancellations, modifications, consternation and fear suggests that Judge Abbott's comments were, with respect, probably incorrect. Event organisers certainly appeared to feel justified in their alarm. 
Autonomy, adventure recreation and the law

The reactions to the Andersen prosecution and conviction indicate that the criminal law, by responding to changes in society, can itself have both positive and negative effects on society. In the New Zealand context, we argue that in respect of the Andersen conviction, the criminal law initially responded more to the rise of a new social cost (accidents from adventure recreations) than to the rise of a new social benefit (recreational and health values associated with adventure recreations), and that this is problematic. As we have illustrated above, one of the central values of recreation is freedom and one of the central values in adventure recreation is autonomy in facing risk. It is our view that because adventure recreations involve voluntary risk-seeking for recreational purposes, accidents ought to be investigated with a view to balancing the risk management responsibilities of both event organisers and event participants. That is, investigations ought to consider the autonomy of the participant as well as the responsibilities of organisers because the overall effect of the criminal law, if applied too strictly, may be that event organisers either do not run adventure events at all, or do run them with rules that restrict participants' freedom to control their own destinies within the event. Either way, in a wider sense, autonomy to run one's life as one wishes is diminished. As Simester and Brookbanks (2002) argue, the criminal law should not unnecessarily restrict the individual autonomy that is the basis of liberal democratic societies:

Within the limits of harm and offence, individuals should be left free by the State to pursue their own goals and priorities. There are a number of reasons to oppose the overuse of criminal law ... [t] he most important consideration is autonomy ... if the law is to respect the right of citizens to control their own lives, it should not deprive them of that control without good reason ...There are already thousands of things the State forbids. Autonomy requires us to have good reason before extending the reach of the criminal law (pp10-11).

We suggest that, as in Le Race 2001, all accidents in adventure recreation events will necessarily involve actions and/or inactions by both organisers and affected participants. In the Le Race case, for example, the organiser's choice of event route, her traffic management arrangements and written and verbal instructions to participants, among other things, contributed to decisions participants made about how they would ride the race and therefore to event outcomes. On the other side of the coin, participants' desires to obtain recreational values from the event by either riding fast or at a more leisurely pace, by cutting corners to gain race advantage or not, by abiding by the race rules or not, also contributed to event outcomes. Being free to make decisions about how they participate is a major part of the attraction of adventure recreation for participants. Without individual decision-making in the face of uncertainty (risk), there would be no adventure. In order to safeguard the recreational values of adventure recreation, then, it seems reasonable to seek criminal justice only in cases where event organisers can be proven to have departed in some major way from reasonable event management practice, and not when they have made only a mere error. In other words, we are saying that it is appropriate for event organisers to only be criminally liable when they are grossly negligent. If simple negligence is the test, then event organisers may understandably restrict or withdraw their services because a mere error on their part, combined with the behavioural contribution of the participant, could produce accidents and result in criminal liability. A gross negligence test would require that the organiser had 
behaved in a way that made an accident likely, regardless of the behaviour of participants, and that would not be in the best interests of recreational participation nor society in general.

\section{Bar Too High}

The Andersen conviction perturbed not just the recreation community but some in the legal community as well. This became evident during the Appeal Court hearing ( $\mathrm{R} v$ Andersen [2005]) when the judges prompted the appellant to return to an argument previously made at the pre-trial hearing: that s145 of the Crimes Act 1961 required proof of recklessness rather than negligence. The technical legal arguments surrounding the wording of s145 are beyond the scope of this paper but in broad terms what the Court of Appeal decided was that that phrase 'knew would endanger' was properly interpreted to mean that a defendant must have actual knowledge that a specific act or omission on their part will create a danger to others. That is, they must know that their act or omission will expose others to danger and go ahead and do the act or omit to do the duty anyway. This constitutes recklessness, a wanton disregard for the health and safety of others.

The Court of Appeal held that having a general awareness that one's acts or omissions could cause danger but not knowing that one had actually done such an act or made such an omission, does not constitute an offence under s145. For Astrid Andersen, then, because the Crown could not prove recklessness, the conviction was overturned. Event organisers throughout New Zealand may have felt relieved at this decision but it is worth considering whether or not participants are well served by it.

We have argued, above, that gross negligence is a more appropriate requirement for criminal nuisance in recreation contexts, and particularly in adventure recreation contexts, in New Zealand. By raising the criminal liability bar from mere negligence to recklessness, we suggest that the Appeal Court judges may have tipped the balance of responsibilities too far in the opposite direction. To be criminally liable under s145, event organisers now have to know that they are taking risks with other people's lives and take those risks regardless - a level of irresponsibility that we argue is detrimental to New Zealand recreation and society in that it may exclude behaviour which ought be discouraged by the criminal law. We favour a mid-point between mere negligence and recklessness: gross negligence. Event organisers, particularly those organising adventure recreation events, should face criminal prosecution if their behaviour constitutes a major departure from the behaviour expected of event organisers in general. As the law stands at present, event organisers may make gross errors, albeit unknowingly, and not face penalties under the Crimes Act. As an example, an organiser could unknowingly completely fail to warn participants of traffic conditions, or river conditions, then have a serious accident or fatality in their event and not be prosecuted for a crime. We cannot agree that this is a satisfactory state of affairs for New Zealand recreation.

The recommendation made by Sir Duncan McMullen in 1995 in respect of s145 was one pathway that could have been taken to remedy the problematically low bar to liability, but this pathway has been closed off by the Andersen Appeal decision. By making their interpretation of the statute, the Appeal Court judges have precluded the possibility of liability for gross negligence under s145. As a challenge to their decision in the Supreme Court (the highest court in New Zealand) is unlikely, an Act of Parliament to alter the wording of s145 or to create separate legislation for recreation will be required to bring New 
Zealand law of criminal nuisance into line with what we argue is a reasonable level of culpability for recreation event organisers.

\section{Conclusion}

In this paper we have argued that the New Zealand law regarding criminal nuisance and criminal negligence was too tough for sport and recreation until 2004 and is now not tough enough. We have taken a particular position on this issue for the purpose of engaging debate in an area of law that is becoming increasingly problematic for sport and recreation in New Zealand.

We argue that New Zealand law was out-of-step with that of comparable countries, but we are not suggesting that New Zealand simply follow the law elsewhere. Whilst in the other common law jurisdictions of England, Canada and Australia mere carelessness and inadvertence are not culpable and there is more onus being placed on the participant and less on the organiser to take care and to assess the risk, the decision to change New Zealand law however should not be based on what the Australian, English and Canadian courts and parliaments are doing but on what is appropriate for New Zealand society and its sporting and recreational practices.

If the threshold of criminal negligence is reduced to gross negligence or 'major departure', we suggest it will encourage careful management of sport and recreation provision and punish 'sloppy' management practice. It will require recreation managers to adhere to standards that are deemed acceptable by the society in which they operate and that change as that society changes. This will be in the best interests of sport and recreation, including adventure recreation, in New Zealand. 
Notes.

1. Search conducted on 13.10.2003. Data from 2003 and 2004, rather than more recent years, are used here to be provide contextual consistency with the criminal prosecution discussed.

2. 'Boy racer' is a colloquial term for those who engage in unauthorised street and drag racing, wheel spins ('donuts'), and/or who pour petrol, diesel and other substances on roads to effect wheel spins, etc. On 1 May 2003, the Land Transport (Unauthorised Street and Drag Racing) Amendment Act can into force

(www.police.govt.nz/service/road/boyraceract.php) and the Christchurch City Council considered how to provide for the recreational needs of this group (Christchurch Press, 9.12.2003). 
Cases

R v Andersen [2003] DCR 506.

R v Andersen, Unreported. (DC, Christchurch, T 021347, 29 August 2003, Judge TM Abbott).

R v Andersen [2005] 1 NZLR 774

R v Mwai [1995] 3 NZLR 149

R v Yogasakaran [1990] 1 NZLR 399

R v. Tomasi. Unreported. (HC, Wellington, AP 255-97, 3 July 1998, Goddard J.)

R v. Hare. Unreported. (HC, Hamilton, T 990677, July 20 1999, Penlington J.). See also: R v Hare, Unreported. (CA, CA332/99, 19 November 1999, Elias CJ, Keith and Pankhurst JJ).

\section{References}

Addison, G. (1999) Adventure Travel and Ecotourism. In J.C. Miles \& S. Priest (eds) Adventure Programming. State College, Pennsylvania, Venture Publishing, Inc., 415-30.

Burrell, R. (c. 1982) Fifty Years of Mountain Federation 1931-1981. Wellington, Federated Mountain Clubs of New Zealand.

Callander, M \& Page, S. J. (2003) Managing risk in adventure tourism operations in New Zealand: a review of the legal case history and potential for litigation. Tourism Management, 24(1), 13-23.

Campbell, I.B. (1996) Compensation for Personal Injury in New Zealand. Its Rise and Fall. Auckland, Auckland University Press.

Campos, P.F. (1998) Jurismania. The Madness of American Law. Oxford, Oxford University Press.

Christoffel, T. \& Teret, S.P. (1993) Protecting the Public. Legal Issues in Injury Prevention. Oxford, Oxford University Press.

Cloke, P. \& Perkins, H.C. (1998) 'Pushing the Limits': Place Promotion and Adventure Tourism in the South Island of New Zealand. In H.C. Perkins \& G. Cushman, (eds) Time Out? Leisure, Recreation and Tourism in New Zealand and Australia. Auckland, Longman, 271-87.

Craig, C.L. \& Cameron, C. (2004). Increasing Physical Activity. Assessing Trends from 1998-2003. Canadian Fitness and Lifestyle Institute, Ottawa, Ontario, available at www.cflri.ca/cflri/pa/surveys/2002_survey/2002 survey.html (Accessed 14.7.2004). 
Creyer, E.H., Ross, W.T. \& Evers, D. (2003) Risky Recreation: and exploration of factors influencing the likelihood of participation and the effects of experience. Leisure Studies, 22, 239-53.

Csikszentmihalyi, M. \& Csikszentmihalyi, I (1999) Adventure and the Flow Experience. In J.C. Miles \& S. Priest (eds) Adventure Programming. State College, Pennsylvannia, Venture Publishing, 153-58.

Department of Conservation (1995) Review of the Department of Conservation. Wellington, Department of Conservation.

Devlin, P.J. \& Booth, K.L. (1998) Outdoor Recreation and the Environment: Towards an Understanding of the Recreational Use of the Outdoors in New Zealand. In H.C. Perkins, \& G. Cushman, (eds) Time Out? Leisure, Recreation and Tourism in New Zealand and Australia. Auckland, Longman, 109-26.

Duncan, G. (2002) Workers' Compensation. In: M. Lloyd (ed) Occupational Health and Safety in New Zealand. Contemporary Social Research. Palmerston North, Dunmore Press, $19-42$.

Eiser, R. (1994) Attitudes, Chaos and the Connectionist Mind. Oxford, Blackwell.

Eiser, R, Cleisson, M. \& Loose, J. (1998) Attitudes, beliefs and other minds: Shared representations in self-organising systems. In S. Read \& L. Miller (eds) Connectionist Models of Social Reasoning and Social Behaviour. Mahwah NJ, Erlbaum, 313-54.

Ewert, A. W. (1989) Outdoor Adventure Pursuits: Foundations, Models, and Theories. Colombus, Ohio, Publishing Horizons.

Ewert, A. \& Hollenhorst, S. (1989) Testing the Adventure Model: Empirical Support for a Model of Risk Recreation Participation. Journal of Leisure Research, 21, 124-39.

Fluker, M.R. \& Turner, L.W. (2000) Needs, Motivations and Expectations of a Commercial WhiteWater Rafting Experience. Journal of Travel Research, 38, 380-89.

Furedi, F. (1997) Culture of Fear. Risk-Taking and the Morality of Low Expectation. London, Cassell.

Grieve, S. (2004) Criminal Liability For Event Organisers - Le Race 2001 Case. Outdoor Update, February.

Harkess, J. (2002) 'Danger' Sports and the spectre of criminal negligence. Law Institute Journal, 76(11), 48-53.

Hawke, G (1992) Economic Trends and Economic Policy, 1938-1992. In G.W. Rice (ed) The Oxford History of New Zealand, Second Edition. Auckland, Oxford University Press, 436-50. 
Hood, C. \& Jones, D.K.C. (eds) (1996) Accident and Design. Contemporary Debates in Risk Management. London, UCL Press.

Horlick-Jones, T. (1996) The Problem of Blame. In C. Hood \& D.K.C. Jones, (eds) Accident and Design. Contemporary Debates in Risk Management. London, UCL Press, 161-71.

Hunt, G. (2005) Weight of Evidence, New Zealand Listener, 198 (3390), 28-31.

Johnston, A.N. (1996) Blame, Punishment and Risk Management. In: C. Hood \& D.K.C. Jones, (eds) Accident and Design. Contemporary Debates in Risk Management. London, UCL Press, 72-83.

Jones, D. \& Hood, C. (1996) Introduction. In: C. Hood and D.K.C. Jones, (eds) Accident and Design. Contemporary Debates in Risk Management. London, UCL Press, 1-9.

Kelly, J. R. (1990) Leisure. Second edition. New Jersey, Prentice Hall.

Mahon Report. [Report of the Royal Commission to Inquire into the Crash on Mount Erebus, Antarctica of a DC10 Aircraft operated by Air New Zealand Ltd (1981)]. Appendix to the Journals of the House of Representatives of New Zealand, 1981, H1.

McKerrow, B. \& Woods, J. (1994) Coast to Coast. The Great New Zealand Race. Christchurch, Shoal Bay Press.

McMullin, Sir D. [Report of Sir Duncan McMullin to Hon Douglas Graham, Minister of Justice, On Sections 155 and 156 of the Crimes Act 1961 (1995).] Wellington, Department of Justice.

Molloy, T. (2001) Criminal Liability for sporting Accidents', The ANZSLA Commentator, November.

Mortlock, C. (1987) The Adventure Alternative. Milnthorpe UK, Cicerone Press.

Neulinger, J. (1981) The Psychology of Leisure. Second edition. Springfield Illinois, Charles C Thomas.

Noble Report. [Commission of Inquiry into the Collapse of a Viewing Platform at Cave Creek near Punakaiki on the West Coast 1995 (1995)]. Wellington, Department of Internal Affairs.

Anon (2003). What's On. Highlights North to South. North and South, November, 119.

Pidgeon, N., Kasperson, R. \& Slovic, P. (eds) (2003) The Social Amplification of Risk. Cambridge, SUP.

Priest, S. (1999) The Adventure Experience Paradigm. In J.C. Miles \& S. Priest, Adventure Programming. State College, Pennsylvania, Venture Publishing, 159-62. 
Rennie, D. (1995) Compensation for Work-Related Injury. In: C. Slappendel (ed) Health and Safety in New Zealand Workplaces. Palmerston North, Dunmore Press, 117-56.

Rice, G.W. (1992) A Revolution in Social Policy, 1981-1991. In G.W. Rice (ed) The Oxford History of New Zealand, Second Edition. Auckland, Oxford University Press, Auckland, 48990.

Rowe, N. \& Moore, S. (2004) Briefing Note for the General Household Survey, 2002. Sport England Research, Sport England, available at:

www.sportengland.org/briefing_note_for_the_general_household_survey_2002.pdf, (Accessed 14.7.2004).

Rowe, N., Beasley, N., \& Adams, R. (2004) Sport, Physical Activity and Health: future prospects for improving the health of the nation. In: Driving Up Participation: the challenge for sport. Academic review papers commissioned by Sport England, April, available at: www.sportengland.org/driving up participation the challenge for sport.pdf) (Accessed 14.7.2004).

Simester, A.P. \& Brookbanks, W.J. (2002) Principles of Criminal Law. Second edition. Wellington, Brookers.

Sport and Recreation New Zealand (SPARC) (2003) Issues for Event Organisers in New Zealand. Discussion Paper (December). Wellington, Sport and Recreation New Zealand, Wellington.

State Services Commission (1998) Assessment of the State of the New Zealand Public Service. Occasional Paper 1. Wellington, State Services Commission.

Standing Committee on Recreation and Sport (2003) Participation in Exercise, Recreation and Sport, 2002. Standing Committee on Recreation and Sport, Australia, available at: www.ausport.gov.au/fulltext/2003/scors /ERASS.pdf (Accessed 14.7.2004).

Van Aalst, I., Kazakov, D. \& McLean, G. (2003) Participation in sport and active leisure by New Zealand Adults. Wellington, Sport and Recreation New Zealand, available at: www.sparc.org.nz/research/participation_adult.php (Accessed 14.7.2004).

Wells, C. (1995) Negotiating Tragedy. Law and Disasters. London: Sweet and Maxwell.

Wells, C. (1996) Criminal Law, Blame and Risk: Corporate Manslaughter. In C. Hood \& D.K.C. Jones, (eds) Accident and Design. Contemporary Debates in Risk Management. London, UCL Press, 50-60.

Zuckerman, M (1990) The Psychophysiology of Sensation Seeking. Journal of Personality, $58,313-45$.

Websites:

'Runnersweb' (www.runnersweb.com), accessed 13.1003. 
Multisport Calendar for the South Island of New Zealand (w3.to/calendar), accessed 13.10.03.

Coast to Coast website (www.coasttocoast.co.nz/kayak_regs.htm), accessed 7.5.2004. Southern Traverse website

(www.southerntraverse.com/southerntraverse/2004/2004_event_info.html), accessed 7.5.2004.

Tourism Research Council website

(http://www.trenz.govt.nz/Surveys/International+Visitor+Survey/Data+and+Ana lysis/Table-Travel-Style-In-NZ.htm), accessed 25.4.06. 
Table 1: Level of Physical Activity - Comparison between countries.

\begin{tabular}{|c|c|c|c|}
\hline & $\begin{array}{l}\text { Physically or } \\
\text { Moderately Active }\end{array}$ & $\begin{array}{l}\text { Participate at least } \\
\text { once over 12 } \\
\text { months }\end{array}$ & Physically Inactive \\
\hline & \% adult population & \% adult population & \% adult population \\
\hline $\begin{array}{c}\text { New Zealand } \\
\text { (data from 2001) }\end{array}$ & 68 & 98 & 2 \\
\hline $\begin{array}{c}\text { Australia } \\
\text { from 2002) } \\
\text { from 202 }\end{array}$ & 59.5 & 77.8 & 12.2 \\
\hline $\begin{array}{c}\text { England } \\
\text { from 1998) }\end{array}$ & 30 & 62 & 38 \\
\hline $\begin{array}{c}\text { Canada } \\
\text { fdata } \\
\text { from 2001) }\end{array}$ & 44 & - & 56 \\
\hline
\end{tabular}

Sources: 1. Van Aalst, et al (2003).

2. Standing Committee on Recreation and Sport (2003)

3. Rowe, et al (2004).

4. Craig and Cameron (2004).

Note: the 4 year span within which the data sets were collected is of little consequence for our purposes here; overall recreational physical activity has been declining in all these countries over the past two decades so the oldest data provides, if anything, a statistical advantage over the more recent data, but to no useful effect. 
Table 2: Participation Statistics - Percentage of adult population participating in selected activities for period given prior to survey.

\begin{tabular}{|c|c|c|c|c|}
\hline Country & \multicolumn{2}{|c|}{$\mathrm{NZ}^{1}$} & Australia $^{2}$ & England \\
\hline & $\begin{array}{l}\text { Last } 4 \\
\text { weeks }\end{array}$ & $\begin{array}{l}\text { Last } 12 \\
\text { months }\end{array}$ & $\begin{array}{l}\text { Last } 12 \\
\text { months }\end{array}$ & $\begin{array}{l}\text { Last } 4 \\
\text { weeks }\end{array}$ \\
\hline Activity & $\%$ & $\%$ & $\%$ & $\%$ \\
\hline Aerobics/fitness & 4 & 10 & 14.6 & $12^{4}$ \\
\hline Cycling & 8 & 15 & 9.3 & $9^{4}$ \\
\hline Fishing & & 25 & 2.3 & \\
\hline Golf & & 18 & 8.7 & \\
\hline $\begin{array}{l}\text { Equestrian/horse } \\
\text { riding }\end{array}$ & & 5 & 1.2 & \\
\hline Ice/snow sports & & 6 & 1.6 & \\
\hline Motor sports & & 6 & 0.9 & \\
\hline Netball & & 7 & 4.1 & \\
\hline Running & & 14 & 7.6 & \\
\hline Sailing & & 5 & 0.9 & \\
\hline Soccer - outdoor & & 5 & 7.4 & \\
\hline Surf sports & & 7 & 2.2 & \\
\hline Swimming & 16 & 36 & 14.9 & $14^{4}$ \\
\hline Triathlon & & 1 & 0.4 & \\
\hline $\begin{array}{l}\text { Bush walking / } \\
\text { tramping }\end{array}$ & & 12 & 5.6 & \\
\hline Walking (other) & 64 & 72 & 30.8 & $45^{3}$ \\
\hline
\end{tabular}

Sources:1. Van Aalst, et al (2003).

2.Standing Committee on Recreation and Sport, 2003.

3. Rowe, et al (2004).

4. Rowe and Moore (2004). 
Table 3: International visitor numbers participating in selected adventure recreations.

\begin{tabular}{|l|c|c|}
\hline Activity & $1992 / 3$ & 2004 \\
\hline Bungy-jumping & Combined total & 770,472 \\
\cline { 1 - 1 } Mountain/climbing & of 50,000- & 814,122 \\
\cline { 1 - 1 } \cline { 3 - 3 } Caving & 100,000 & 820,867 \\
\cline { 1 - 1 } \cline { 3 - 3 } Mountain biking & & 906,782 \\
\cline { 1 - 1 } Rafting & $200,000+$ & 731,226 \\
\hline Jet Boating & $\begin{array}{l}\text { Cloke and } \\
\text { Perkins (1998), } \\
\text { p274. }\end{array}$ & $\begin{array}{l}\text { Tourism Research } \\
\text { Council website }\end{array}$ \\
\hline
\end{tabular}

